 \\ Ryan Goss, Criminal Fair Trial Rights: Article 6 of the European Convention on Human Rights \\ McDermott , $Y$.
}

\section{Human Rights Law Review}

DOI:

$10.1093 / \mathrm{hrlr} / \mathrm{ngv} 021$

Published: 20/07/2015

Peer reviewed version

Cyswllt i'r cyhoeddiad / Link to publication

Dyfyniad o'r fersiwn a gyhoeddwyd / Citation for published version (APA):

McDermott , Y. (2015). Ryan Goss, Criminal Fair Trial Rights: Article 6 of the European

Convention on Human Rights. Human Rights Law Review. https://doi.org/10.1093/hrlr/ngv021

\section{Hawliau Cyffredinol / General rights}

Copyright and moral rights for the publications made accessible in the public portal are retained by the authors and/or other copyright owners and it is a condition of accessing publications that users recognise and abide by the legal requirements associated with these rights.

- Users may download and print one copy of any publication from the public portal for the purpose of private study or research.

- You may not further distribute the material or use it for any profit-making activity or commercial gain

- You may freely distribute the URL identifying the publication in the public portal ?

Take down policy

This is a pre-copyedited, author-produced PDF of an article accepted for publication in 'Human Rights Law Review' following peer review. The version of record for Yvonne McDermott, 'Ryan Goss, Criminal Fair Trial Rights: Article 6 of the European Convention on Human Rights' is available online at: doi:10.1093/hrlr/ngv021

Take down policy

If you believe that this document breaches copyright please contact us providing details, and we will remove access to the work immediately and investigate your claim. 
Ryan Goss, Criminal Fair Trial Rights: Article 6 of the European Convention on Human Rights (Hart Publishing, 2014, xviii + 208pp, £60) ISBN 978-1-84946550-2 (hb)

Criminal Fair Trial Rights by Ryan Goss represents an important and timely contribution to the literature on the most litigated provision of the European Convention on Human Rights (ECHR), ${ }^{1}$ Article 6. Unlike many of the leading texts on fair trial rights under the ECHR, which undertake a right-by-right analysis, ${ }^{2}$ Goss takes a refreshing issue-based approach to determine the extent to which the case law of the European Court of Human Rights (ECtHR) on Article 6 is consistent, predictable, clear and stable. He ultimately concludes that there is significant incoherence in the ECtHR's approach(es) to questions such as the identification of implied rights, the interpretation of Article 6, its own role in relation to Article 6, and the assessment of breaches.

In Part A of the book, Goss discusses the interpretative techniques used by the ECtHR, and finds considerable inconsistency in the way that the Court uses extrinsic documents and avoids literal interpretation (pp 15-34). One particularly interesting nugget point that arises from this Part is that the ECtHR's use of the 'object and purpose' of Article 6 is somewhat confused. On occasion, it is invoked without explanation as to why recourse to a teleological approach is warranted, and, perhaps more worryingly, the ECtHR has, on occasion, made reference to the underlying purpose of a provision without explicitly stating what that purpose was (p 20).

Another important contribution appears in Ppart B, where Goss analyses the Court's position under the so-called 'fourth instance doctrine', which determines that its role should not be as a further court of appeal for national decisions. Goss determines that this rule is not as clear-cut as commonly assumed, with reference to a number of exceptions to the doctrine enunciated in the case law of the ECtHR. He highlights a number of fascinating examples where the ECtHR clearly did undertake its own analysis of the factual and legal findings reached by the domestic court ( $p$ $50-51)^{3}$

Part C discusses the ECtHR's interpretation of the internal structure of Article 6 - that is, whether the minimum guarantees enunciated in Article 6(3) are to be properly understood as elements or specific aspects of the general right to a fair and public hearing under Article 6(1); and ${ }_{2}$ if so, how should-alleged violations of both Articles 6(1) and 6(3) should be assessed? This is perhaps the section of the book where Goss is at his most

\footnotetext{
${ }^{1}$ Roberts, 'Does Article 6 of the European Convention on Human Rights Require Reasoned Verdicts in Criminal Trials?' (2011) 11 Human Rights Law Review 213 at 214.

${ }^{2}$ These include: Stavros, The Guarantees for Accused Persons under Article 6 of the European Convention on Human Rights (1993); Trechsel, Human Rights in Criminal Proceedings (2006); Emmerson, Ashworth and Macdonald, Human Rights and Criminal Justice (2012).

${ }^{3}$ Amongst other examples provided by Goss, the discussion of Nechiporuk and Yonalko $v$ Ukraine Application No 42310/04, Merits and Just Satisfaction, 21 April 2011 is particularly illuminating.
} 
prescriptive - in other parts, he categorically refuses to suggest a route for the ECtHR's future practice or to draw normative conclusions on the ECtHR's judgments, which some readers may find frustrating. ${ }^{4}$ For example, in the discussion of 'dogs that did not bark' - implied rights that were not recognised by the ECtHR - Goss explicitly refuses to be drawn on whether the Court's decisions were correct ( $p$ 104-105). By contrast, in Part C, Goss explicitly advocates a return to the approach taken by the European Commission in Nielsen $v$ Denmark, where it considered that Articles 6(2) and 6(3) provided specific essential elements of the general notion of a fair trial, and that it would still be possible to find that Article 6 had been violated, even where those minimum elements had been respected (p 86-87). ${ }^{5}$ This approach would require the Court to consider, first, whether there have been any specific violations of Article 6(2) or Article 6(3), and only if that question is answered in the negative will would the Court consider whether the trial as a whole was unfair.

This point relates closely to Part E of Criminal Fair Trial Rights, which Goss describes as 'the heart of this book' ( $p$ 115). A particularly important section of Part E deals with the 'proceedings as a whole' test, where the author shows that this test has been applied inconsistently and ambiguously. Akin to the other sections in the book, Goss concludes that the ECtHR's approach is too unclear to provide sufficient guidance, stating that 'irrational flexibility means that the Court can approach an individual application in an unpredictable multitude of ways' (p 206), leaving potential applicants uncertain as to the probable success of their claim. The author's future work could perhaps assess the impact of the ECtHR's incoherence in the interpretation of its rulings by national courtsin domestic jurisdictions in practice, or how the ambiguity of some of the standards laid down by the Court has allowed Article 6 case law to be misapplied or even abused in other contexts. ${ }^{6}$

Criticisms of the book can be limited to two relatively minor points. The first is stylistic: some readers may find the signposting, whereby each chapter tells us what each section will argue and each section in turn begins by telling us again what that section will argue, somewhat superfluous. Moreover, perhaps, given that a large theme of the book is consistency, the footnoting style is remarkably inconsistent - sometimes authors' full names are given, in other places, the author's first initial only is used, and there does not appear to be a clear rule in place for this. These minor points could be easily remedied in future editions of the book.

The second potential criticism is that readers might find some of the arguments slightly pedantic. Some aspects, which judges may regard as

\footnotetext{
${ }^{4}$ cf Hoyano, 'Publication Review: Criminal Fair Trial Rights: Article 6 of the European Convention on Human Rights' [2015] Criminal Law Review 243.

${ }^{5}$ Nielsen v Denmark Application No 343/57, Commission Report 15 March 1961.

${ }^{6}$ A conference on "The "Cross-Fertilization" Rhetoric in Question: The Use and Abuse of the European Court's Jurisprudence by International Criminal Tribunals' was held at Edge Hill University in June 2014.
} 
mere rhetorical flourishes, such as emphasising 'the prominent place held in a democratic society by the right to a fair trial', ${ }^{7}$ are criticised for not being more explicit as to why the fair trial holds an important place in a democratic society, and what impact this prominent position has on the interpretation of Article 6 (p 30-34). The author's argument in this regard might have been strengthened in pointing to real impacts of this approach.

Overall, this book will be a welcome addition to the bookshelves of public international law and human rights scholars and practitioners. Its conclusions will likely cause these individuals, as well as national and other international institutions, to rethink the true meaning and value of ECtHR case law when incorporating and interpreting various ECHR concepts such as the 'proceedings as a whole' test and the 'fourth instance doctrine', given the problems of incoherence that Goss has cogently identified.

\section{Yvonne McDermott}

Lecturer in Law

Bangor University, UK

${ }^{7}$ Somogyi v Italy Application No 67972/01, Merits and Just Satisfaction, 18 May 2004, at para 72. 